\title{
(2ustomers' Expectation towards Online aBe Marketing: A Study on Some Economic Zone in Research House Bangladesh
}

\author{
Md. Shariful Alam Khandakar'1, Md. Rakib Uddin Bhuiyan², Humaira Siddika ${ }^{3}$ \\ ${ }^{1}$ Assistant Professor, Department of Tourism and Hospitality Management, University of Dhaka, BANGLADESH \\ ${ }^{2}$ Assistant Professor, Department of International Business, University of Dhaka, BANGLADESH \\ ${ }^{3}$ Lecturer, Department of Business Administration, Dhaka City College, BANGLADESH \\ *E-mail for correspondence: sharif@du.ac.bd
}

Received: Jun 04, 2017;

Accepted: Nov 25, 2017;

Published: Jan 01, 2018

Source of Support: Nil

No Conflict of Interest: Declared

\begin{abstract}
This paper attempts to analysis the customers' expectation towards online marketing in Bangladesh. First, it evaluates the impact of independent variables (factors of online marketing) on dependent variable (customers' satisfaction). In order to do so a survey was conducted through questionnaire and data collected from 200 respondents'. Samples (Individuals and corporate firms) were selected from three economic zones and multiple regression analysis was conducted for the study. It also evaluates customers' expectation from online marketers. Moreover the study highlights the online marketing strategies. Next, the study focuses on the benefits from online marketing. It also identifies the problems and challenges to develop online marketing strategies. Online marketing opens huge opportunities for marketer and customer where the ratio of benefit is higher than the ratio of costs. Finally, the study provides specific ways to solve the problems emphasizing on online marketing principles and to avail the opportunity to cope with the today's competitive market. The strategies require continuous improvement and it is expected to be more dynamic in future.
\end{abstract}

Keywords: Internet, E-Business, E-Commerce, B2B, B2C, C2B, C2C, E-marketing, Online marketing strategy

\section{INTRODUCTION}

Online marketing (also known as internet marketing, emarketing, search marketing and web marketing) is the marketing of products and services through the use of internet. The internet is always updating and evolving. Marketing strategies need to advertise on it require products and services to the customers and keep on evolving and updating as well. The web changes constantly, every day more and more consumers turn to internet and search engines to look for information. The advent of the new media and internet have increased possibilities of online marketing and internet retailing with new features of interactive shopping, pod casting and emarketing. Consumers are connected to online shopping sites with $\mathrm{Wi}-\mathrm{Fi}$, internet or $3 \mathrm{G}$ mobile phones. Ecommerce has taken a new dimension in retailing with increasing number of people shopping online and even making flight bookings online (Papers4you.com, 2006).

The internet is an international network and online marketing is the fastest growing form of direct marketing. Recent teleological advances have created a digital age
(Kotler, Bowen and Makens, 2010). The rapid growth of the web, subsequent bursting of the dot-com bubble, and current mainstreaming of the internet and related technologies created today's climate of marketing convergence; the comprehensive integration of online marketing and traditional marketing to create seamless strategies and tactics. Wide spread use of the internet is having a dramatic impact on both buyers, marketers and other channel members who serve them. The internet evaluated at 1957 when Russia launched the Sputnik satellite and thereby the space race. In the cold war era, Russia led in this race was caused for great concern. In order to close the gap, President Eisenhower created ARPA, soon DARPA (Defense Advanced Research Projects Agency). The planners at ARPA believed that they could use the research mandate to develop an attack-proof communications structure for national defense purposes. Between 1982 and 1987 the foundations of the modern internet were laid. One of these foundations was TCP/IP (Transmissions Control Protocol/Internet Protocol) the standard language of all internet programming (Roberts, 2003). Customer satisfaction is the most important aspect 
of business development through e-marketing for truly enhances the worth of business.

\section{OBJECTIVES OF THE STUdY}

The main objective of the study is to determine the Customers' expectations from Online Marketing in Bangladesh. The specific objectives of the study are:

- To explore the major online marketing domains of Bangladesh.

- To reveal customers' satisfactions toward online marketing.

- To find out some strategies of online marketing to improve online business in Bangladesh.

- To determine some possible ways of overcoming those problems and challenges which are encountered with online marketing.

\section{LITERATURE REVIEW}

Internet marketing, also known as digital marketing, web marketing, online marketing, search marketing or emarketing, is referred to as the marketing (generally promotion) of products or services over the internet (www.coremetrics.com/downloads/bw2brief.pdf). It also refers to use the power of internet advertisement to generate or trespasser (uk.wikipedia.org). E-marketing allows firm and marketer to cater to the needs of individual customers (Watson, Leyland, Berthon. and Zinkham, 2002). E-marketing affects traditional marketing in two ways. First, it increases efficiency and effectiveness in traditional marketing functions; second, the technology of e-marketing transformation results in new business models that add costumers value and/or increase company profitability (Strauss, Ansary and Frost, 2006). Internet marketing is associated with several business models: E-commerce, Lead-based websites Affiliate Marketing (Twangcafe, 2010). Electronic business methods enable companies to link their internal and external data processing systems more efficiently and flexibly, to work more closely with suppliers and partners, and to better satisfy the needs and expectations of their customers (www. Wikipedia.org/wiki/electronic business). Ebusiness is carrying out the goal of business through utilization of the internet (Ferrell, 2009) E-business is the continuous optimization of a firm's business activities through digital technology (Strauss and Frost, 2009). By trading online one can save time and money, reduce overheads and reach a much wider market and any one make it easier for customers to do business with marketers (www.business.gov.au). Electronic commerce, commonly known as e-commerce, e-commerce or e-comm., refers to the buying and selling of products or services over electronic systems also includes the entire online process of developing, marketing, selling, delivering, servicing and paying for products and services (www.Wikipedia.org/wiki/electronic commerce). It is an outstanding example of all kind value addition for business in the marketing place (Bala, 2001). It refers to online transactions: selling goods and services on the Internet, either in one transaction or over time with an ongoing subscription price (Strauss, El-Ansary and Frost, 2006). E-commerce involves a number of players such as buyer, seller and the internet service provider (Habib, 2000). E-commerce can facilitate internal interactions, improve customer relations and eliminate the constraints of place and time (Rahman, 2002). But E-commerce has become a popular word frequently used by the people (Azad, 2001).E-commerce has tremendously reduced the transaction costs entailed in purchases, sales, operating, holding inventory and financial cost(Talha,2003). But in Bangladesh, e-commerce is evolving in the last few years; the ball has been rolling for an internet revolution. In the year 2000, there were about 1000pc sold in the country, but it has risen to more than one lakh (Pradip Kumar Panday, 2004). Now it is estimated that more than 180 ISP have been working in this country (www.ispabd.org/news.php) and there are more than 450,000 internet users in the country (UNDESA report 2007). Online marketing has brought about a fundamental shift in national economies that are isolated from each other by barriers to cross border trade and investment; isolated by distance; time zones and language; and isolated by national differences in governmental regulation, culture and business systems(Mohammad'2004). Online marketing is occupying a primary place in today's business for improving business environment. It is important as it helps the organizations to gain a competitive advantages over the competitors and is enabling business to analyze details of customers, buying patterns, taste and preferences so that they can efficiently pitch advertising and marketing campaigns to smaller target market(Baker, 2001).

Bangladesh is yet to be connected to the rest of the world over a fiber-optic backbone. Currently ISPs in Bangladesh are providing Internet services via VSATs from Singapore. The internet is the heart of the online marketing. Bangladesh has entered the internet age in 1996. At present there are roughly 3,70,000 thousand subscribers in the country. Many companies have acquired proficiencies in web page development.

E-Commerce in Bangladesh was actually started in the year 1999 by some non-resident Bangladeshi (Ishtiaque, Habib and Khan, 2002). In Bangladesh, the first B2C ecommerce site is www.munshigi.com and it started at 1999. After that in 2000, www.deshigreetings.com and www.homeviewbangladesh.com opened e-commerce sites. The first B2B e-commerce in Bangladesh is www.bgmea.com. Now, there are more than thirty companies who are using e-commerce application to provide easier services for the consumers.

Online marketing is a strategy - a way to sell or promote something using the Internet. Field of online marketing includes the followings (Richard Hoy, 2006): Affiliate 
Marketing, Content marketing, Referral marketing, Email Marketing, Search Engine Marketing, and Viral Marketing. Affiliate marketing means promoting other people's (Company's) product and earning a commission in return (If a sale is made); (Garish, 2011). Content marketing subscribes to the notion that delivering information to prospects and customers drives profitable consumer action (http://www.entrepreneur.com/blog/220587). Referral marketing is a structured and systematic process to maximize word of mouth potential (Philipp Bernd and Christophe, 2010). Email marketing is directly marketing a commercial message to a group of people using email (Ching, 2004). It usually involves using email to send ads, request business, or solicit sales or donations, and is meant to build loyalty, trust, or brand awareness. Search engine optimization (SEO) is the process of improving the visibility of a website or a web page in a search engine's "natural," or un-paid ("organic" or "algorithmic"), search results, (Danny , 2004). Viral marketing allows users to become part of the advertising experience. At the bare minimum mobile ads with viral abilities can become powerful interactive campaigns (http://www.entrepreneur.com/blog/220587). Online marketing seems to have completely revolutionized marketing techniques although it has limitations on usage, privacy issues and security. Apart from ease and convenience of internet marketing, one major advantage of internet marketing is customization or personalization of products and services to suit the needs and tastes of individual customers (Ho, 2006).

\section{Methodology of the Study}

\section{Sources of information}

Sources of data: Initially the study was carried on by exploring the secondary sources. Later it was supported by primary data. That means both primary and secondary data have been used for the study.

Primary data: Primary data have been collected through structured questionnaire, interview with online marketing customers, consumers and sellers.

Secondary data: secondary data were collected from several recognized journals, magazines, newspaper, articles, research papers, websites, and books and so on.

\section{Sample Design}

The sample size per city was determined randomly on the basis of market share and usage rate of internet. Total sample size of the study is 200; the distributions of the samples are furnished in table 2.

Table 1: Sample Distribution

\begin{tabular}{|c|c|c|c|c|c|}
\hline & Dhaka & Chittagong & Sylhet & Khulna & Total \\
\hline Individuals & 60 & 40 & 25 & 15 & 140 \\
\hline Corporate firms & 25 & 20 & 8 & 7 & 60 \\
\hline Total & 85 & 60 & 33 & 22 & 200 \\
\hline
\end{tabular}

\section{Sampling Method}

Sampling is the technique to take the sample from the population. For this study a survey was conducted considering on some questionnaires. But Non-probability judgment sampling (Malhotra, 2006) has been used to conduct the study.

\section{Variables Used}

Dependent and independent variables have been used for conducting the study. Here, customers' satisfaction is the dependent variable and independent variables are: reliably, responsiveness, assurance, empathy and tangibles.

\section{Tools used}

The structured questionnaire was used as the instrument of data collection. Two sets of questionnaire were used for customers and corporate firms respectively and 5-point likert scale were used in questionnaire (strongly Disagree $=5$, Disagree $=4$, Neutral $=3$, Agree $=2$ and strongly agree $=1$ ). The reliability of the questionnaires was judged from the result of pretest. Finally, generalizing collected data from respondents and other sources of customers' satisfaction was measured using SPSS software in the study.

\section{The OnLine MARKeting Domain}

Online marketing domains include Business to Consumer, Business to Business, Consumer to Consumer, Consumer to Business. These four major online marketing domains have potential to apply in Bangladesh profitably.

Figure 1: Online marketing domains

\begin{tabular}{|c|c|c|}
\hline & $\begin{array}{l}\text { Targeted to } \\
\text { consumers }\end{array}$ & $\begin{array}{l}\text { Targeted to } \\
\text { businesses }\end{array}$ \\
\hline $\begin{array}{l}\text { Initiated by } \\
\text { business }\end{array}$ & $\begin{array}{c}\text { B2C } \\
\text { (Business to } \\
\text { Consumer) }\end{array}$ & $\begin{array}{c}\text { B2B } \\
\text { (Business to } \\
\text { Business) }\end{array}$ \\
\hline $\begin{array}{l}\text { Initiated by } \\
\text { consumer }\end{array}$ & $\begin{array}{c}\mathrm{C} 2 \mathrm{C} \\
\text { (Consumer to } \\
\text { Consumer) }\end{array}$ & $\begin{array}{c}\mathrm{C} 2 \mathrm{~B} \\
\text { (Consumer to } \\
\text { Business) }\end{array}$ \\
\hline
\end{tabular}

Source: http:/ / ezinearticles.com

\section{Businesses-to-Consumers (B2C)}

The ultimate goal of B2C marketing is to convert prospects into customers as aggressively and consistently as possible. B2C companies employ more merchandising activities like coupons, displays, store fronts (both real and internet) and offers to charm the target market to buy. B2C marketing campaigns are concerned with the transaction, shorter in duration and need to capture the customer's interest immediately. These campaigns often offer special deals, discounts, or vouchers that can be used both online and in the store. Online consuming rate grow at a healthy rate (Kotler, Bowen and Makens, 2010). 


\section{Businesses-to-Businesses (B2B)}

$\mathrm{B} 2 \mathrm{~B}$ marketing is to convert prospects into customers; the process is longer and more involved. A B2B company needs to focus on relationship building and communication using marketing activities that generate sales. B2B companies use marketing to educate various players in the target audience because the decision to purchase is usually a multi-step process involving more than one person (Kotler, Bowen and Makens, 2010). B2B marketers also use B2B web sites, e-mail, online product catalogs, online trading networks, and other online resources to reach new business customers, serve current business customers more effectively and efficiently.

\section{Consumer-to-consumer (C2C)}

A large amount Consumer-to-Consumer (C2C) online marketing and communication occurs on the web between interested parties over a wide range of products and services. C2C involves buy or exchange goods or information directly with one another (Kotler, Bowen and Makens, 2010). For example, web logs or blogs, online journals, eBay where people post their thoughts on a narrowly defined topic.

\section{Consumer-to-Business (C2B)}

Most of the companies now invite prospects and customers to send in suggestions, complaints and questions via company web sites. Beyond this, rather than waiting for an invitation, consumers can search out sellers on the web, learn about their offers, initiate purchases, ask questions, offer suggestions, lodge complaints or deliver complaints, and give feedback to companies (Kotler, Bowen and Makens, 2010).

Online marketing or e-marketing is always confused with ecommerce. Any business marketing using online media is known as e-marketing, while on the other spectrum, if there is financial transaction involved with the electronic process using internet technologies; it is e-commerce (Paul Nate, 2010). Online marketing also include the following categories:

Business-to-employee (B2E): Business-toemployee (B2E) electronic commerce uses an intrabusiness network which allows companies to provide products and/or services to their employees. Typically, companies use B2E networks to automate employeerelated corporate processes. For examples of B2E applications include: Online insurance policy management, corporate announcement dissemination, Online supply requests, Special employee offers, employee benefits reporting (White, Jay D., 2007).

Business-to-government (B2G): Business-togovernment $(\mathrm{B} 2 \mathrm{G})$ is a derivative of $\mathrm{B} 2 \mathrm{~B}$ marketing and often referred to as a market definition of "public sector marketing" which encompasses marketing products and services to various government levels - including federal, state and local through integrated marketing communications techniques such as strategic public relations, branding, and advertising and web-based communications. B2G networks provide a platform for businesses to bid on government opportunities which are presented as solicitations in the form of RFPs in a reverse auction fashion (White, Jay D., 2007).

\section{ANALYSIS AND FINDINGS}

\section{Customer Satisfaction}

The mean customer satisfaction for all customers came in 4.35 in a scale of 5, which means consumers are highly satisfied with offerings. In identifying the customer satisfaction, multiple regression analysis was conducted considering five dimensions (reliability, responsiveness, assurance, empathy and tangibles). The model used in analysis is provided in table 3 that shows the independent impact of each variable on customer satisfaction. The adjusted $R$ square value of the study came 0.731 which means the model is very much fit identifying customer satisfaction. Thus 73.1 percent of variation in the customer satisfaction can be explained by the variables, responsiveness, assurance and empathy.

Table 2: Five dimensions of Independent Variables of online marketing

\begin{tabular}{|l|l|}
\hline $\begin{array}{l}\text { Independent } \\
\text { Variables }\end{array}$ & \multicolumn{1}{|c|}{ Attributes } \\
\hline Reliability: & $\begin{array}{l}\text { When firm promises to do } \\
\text { something by a certain time, it will } \\
\text { do so. When a customer has a } \\
\text { problem, the firm will show a } \\
\text { sincere interest in resolving it. The } \\
\text { firm will perform the service right } \\
\text { the first time. }\end{array}$ \\
\hline Responsiveness: & $\begin{array}{l}\text { Employees in the firm will give } \\
\text { prompt service to customers. } \\
\text { Employees in the firm will always } \\
\text { be willing to help customers. } \\
\text { Employees in the firm will never be } \\
\text { too busy to respond to customers' } \\
\text { request. }\end{array}$ \\
\hline Assurance: & $\begin{array}{l}\text { Employees in the firm will be } \\
\text { consistently courteous with } \\
\text { customers. Employees in the firm } \\
\text { will have knowledge to answer } \\
\text { customers' questions. Customers of } \\
\text { the firm will feel safe in their } \\
\text { transactions. } \\
\text { The firm will give customers } \\
\text { personal attention. The firm will } \\
\text { understand the specific needs of } \\
\text { their values. The firm will have } \\
\text { customer's interest at heart. }\end{array}$ \\
\hline $\begin{array}{l}\text { Materials associated with the } \\
\text { service (catalog, brochure \& demo } \\
\text { items) will be visually appealing in } \\
\text { the firm. }\end{array}$ \\
\hline Empathy:
\end{tabular}


Table 3: Regression Results

\begin{tabular}{|c|c|c|c|c|c|}
\hline \multicolumn{6}{|c|}{ Regression Model Summery } \\
\hline $\mathrm{R}$ & $\begin{array}{c}\mathrm{R} \\
\text { Square }\end{array}$ & \multicolumn{2}{|c|}{$\begin{array}{l}\text { Adjusted } \\
\text { R Square }\end{array}$} & \multicolumn{2}{|c|}{$\begin{array}{l}\text { Standard Error } \\
\text { of Estimates }\end{array}$} \\
\hline .868 & .754 & \multicolumn{2}{|c|}{\begin{tabular}{|r|}
.731 \\
\end{tabular}} & \multicolumn{2}{|c|}{.495} \\
\hline \multicolumn{6}{|c|}{ Regression Coefficients** } \\
\hline \multirow{2}{*}{ Model } & \multicolumn{2}{|c|}{$\begin{array}{l}\text { Un-standardized } \\
\text { Coefficients }\end{array}$} & $\begin{array}{c}\text { standardized } \\
\text { Coefficients }\end{array}$ & \multirow[t]{2}{*}{ t value } & \multirow[t]{2}{*}{$\mathrm{p}$ value } \\
\hline & $\mathrm{B}$ & Std. Error & Beta & & \\
\hline 1 (Constant) & -2.354 & 0.520 & & -4.530 & \\
\hline Reliability & 0.151 & 0.033 & 0.367 & 4.609 & 0.000 \\
\hline Responsiveness & 0.055 & 0.027 & 0.164 & 2.058 & 0.044 \\
\hline Assurance & 0.102 & 0.047 & 0.193 & 2.195 & 0.032 \\
\hline Empathy & 0.191 & 0.042 & 0.415 & 4.568 & 0.000 \\
\hline Tangibles & -0.016 & 0.075 & -0.015 & -0.220 & 0.827 \\
\hline
\end{tabular}

From this analysis, It was found that among five variables only four (reliability, responsiveness, assurance, empathy) are significant predictors of customer satisfaction. The empathy dimension is the most significant predictor of customer satisfaction which has value 0.415 that is greater than other dimensions. That means customers become very much influenced by the variable empathy (The firm will give customers personal attention with the specifying needs of their values). On the other hand, responsiveness is small predictor with low value 0.164 of customer satisfaction. That means the influence of responsiveness (employees in the firm are very helpful will give prompt service to customers) is very low on customers satisfaction.

\section{Future Expectation}

In this study customers' future intention is measured in terms of usage rate and switch in searching web pages of certain organizations. The percentage of usage rate determined that urban people are heavy subscribers of online offerings than semi urban and rural. It has been shown in table- 4 .

Table 4: Internet users of Bangladesh (in percentage)

\begin{tabular}{|c|c|c|}
\hline $\begin{array}{c}\text { Users of } \\
\text { Urban areas }\end{array}$ & $\begin{array}{c}\text { Users of Semi } \\
\text { urban areas }\end{array}$ & $\begin{array}{c}\text { Users of } \\
\text { Rural areas }\end{array}$ \\
\hline $88 \%$ & $9 \%$ & $3 \%$ \\
\hline
\end{tabular}

Source: (Rastogi, 2004)

Table-4: Shows that urban people are heavy users of online offerings which were $88 \%$ and semi urban and rural users are $9 \%$ and $3 \%$ consecutively.

Again, the percentage of online buyers (trial, frequent, occasional and regular) has been shown in Table-5).

Table 5: Percentage of online buyers in Bangladesh

\begin{tabular}{|c|c|}
\hline Types of Online Buyers & $\%$ of Online Buyers \\
\hline $\begin{array}{c}\text { Trial - (purchase is part of } \\
\text { experiment) }\end{array}$ & $69 \%$ \\
\hline $\begin{array}{c}\text { Occasional - (make purchase } \\
\text { seasonally) }\end{array}$ & $53 \%$ \\
\hline $\begin{array}{c}\text { Frequent - (purchase } \\
\text { continuously) }\end{array}$ & $26 \%$ \\
\hline $\begin{array}{c}\text { Regular - (make planned } \\
\text { purchase as required) }\end{array}$ & $38 \%$ \\
\hline
\end{tabular}

Source: (Yeasmin and Siddika, 2011)
In table-5, it has been found that the percentage of online buyers regarding trial was higher than other types of purchaser that is $69 \%$ which is $16 \%$ higher than occasional buyers and $43 \%$ higher than frequent purchasers. Only the $38 \%$ was the regular online buyers.

While measuring the switching tendency, a very interesting fact was found. This tendency varies from one industry to another. But very common reasons behind this switching come few factors like availability, frequency, costs, variety of offerings and durability of network and customer service.

Customers' expectation from the online marketing was measured using two questions:

- What type of up gradation do you want in online from the companies?

- What type of change and offer would you introduce if you were the owner of the organization in a certain industry?

A huge number of customers expect a high quality and variations of product and services with low cost which is shown in table-6.

Table 6: Customers' expectation from online marketing (in Bangladesh)

\begin{tabular}{|c|c|}
\hline Customers' expectations & Percentage \\
\hline Low price & $83 \%$ \\
\hline Variations in offer & $74 \%$ \\
\hline Availability of information & $92 \%$ \\
\hline Standard and quality & $77 \%$ \\
\hline After sale service & $57 \%$ \\
\hline
\end{tabular}

Source: Data From the survey of respondents

Table-4 explained, it is evident that most of the customers (83\%) want low price, while some customers (74\%) want variations in offer, $92 \%$ customers want availability of information, $77 \%$ want durability of quality and $57 \%$ want after sale service.

\section{Online Marketing Strategies}

Companies can conduct online marketing in any of the four ways: creating a Web site, placing ads and promotion online, setting up or participating in online social networks, or using e-mail (Kotler, Armstrong, 2010).

Figure 2: Setting up for online marketing

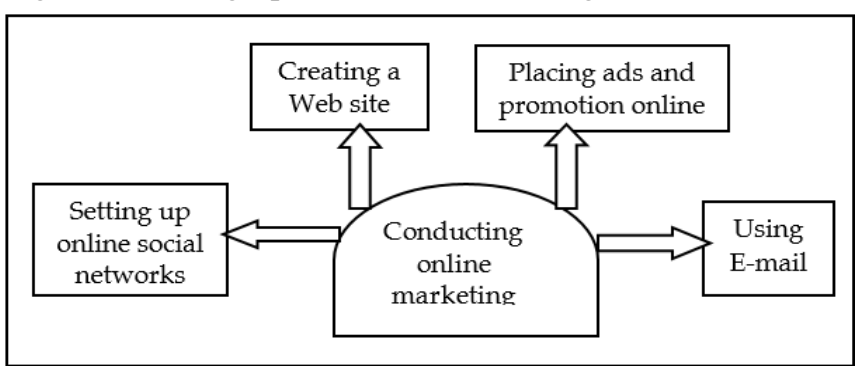

Source: http:/ / ezinearticles.com 


\section{Creating a Web site}

The first step in conducting online marketing is to create a web site. Web site varies greatly by purpose and content.

- Corporate (or brand) web site-designed to sell the company's products directly, build customer goodwill, collect customer feedback, and supplement other sales channels.

- Marketing web site-designed to engage consumers in an interaction that will move them closer to a direct purchase or other marketing outcome.

Companies must constantly update their sites to keep them current, fresh, useful, valuable and excitement. To attract new visitors and to encourage revisits, online marketers should pay close attention to seven Cs of effective web site design (Kotler, Bowen and Makens, 2010).

- Context: The site's layout and design

- Content: The text, pictures, sound, and video

- Community: The ways the site enables user-to-user communication

- Customization: The site's ability of tailor itself to different users or to allow users to personalize the site

- Communication: The ways the site enables site-touser, user-to-site, or two way communication

- Connection: The degree that the site is linked to other sites

- Commerce: The site's capabilities to enable commercial transactions

- Constant change: To keep customers coming back to the site, companies need it (Kotler, Bowen and Makens, 2010).

\section{Placing ads and promotion online}

Banner, Interstitial, Pop-ups, Pop-under, Search-related ads (or contextual advertising), Viral marketing are available form of online advertisement marketer can use these as considers of their requirements.

\section{Setting up or participating in online social networks}

The popularity of the internet creates huge rush on online marketing. Countless independent and commercial web sites have arisen that given consumers online places to congregate, socialize, and exchange views, thought and information.

\section{Using e-mail}

E-mail is a major weapon of online marketing and through using e-mail marketing easy to reach customers (Kotler, Armstrong, 2010).

\section{Problems OF OnLINe MARKeting}

Due to computer crime, cyber fraud, and internet invasion, online marketing may face many problems. In this regard, Cheney (1999) said, “They (cyber criminals) can rob you blind.
They can steal your identity. They can swipe your deepest secrets and sell them to the competition. They can read your email, talk to your vendors, contract your customers, replicate your website, and take orders for your products. They can tap your treasury. They can clog your systems to the point of paralysis. They can sniff through your personnel files. If they run off with your laptop they might extort you till you weep." As a developing nation in the field of technology, Bangladesh has some sort of limitations in online marketing. Some will be automatically solved as the country is advancing towards the direction of newer technology and some need to be solved as early as possible. These are:

- Illegal or unethical online promotion is high: The chance of participating in illegal or unethical online promotion is high for online marketing than traditional marketing.

- $\quad$ Online marketing is costly: Online marketing is not free. The cost of software, hardware, web site design, maintenance of web site, online distribution costs and of course, time, all must be factored into the cost of providing service or product (http:/ /ezinearticles.com).

- No direct or live interaction: An online business can reach less than two out of three householders of the total number of visitors to a business web site; most of them prefer to make live interaction with the dealers when they buy.

- Websites are developed with a marketing view: Most of the businesses organization's websites are developed based on a marketing view not customer view. It may results lack of customer service, inquiry response and poor navigation.

- Lack of security: Security issues are also a concern for many online consumers. The transfer of personal information over the internet is ripe for exploitation by unscrupulous merchants who can sell or give your information to other companies. Generally, the bigger and more well-known the company, the lesser the security risk.

- In online same brand fighting for online visibility: Online marketing is a competitive field where thousands of products with same brand name fighting for online visibility. So getting good visibility and ranking, require customer crowd for the site.

- $\quad$ Lack of power supply: Shortage of power supply felt great impact on online marketing. Our country has huge shortage of power supply that is why customer can't operate computer at their needed times that hamper online marketing activities. 
- Limited access of telecommunication and internet connectivity: Our country has limited access of telecommunication and internet connectivity that slower the expansion rate of online marketing.

\section{RECOMMENDATIONS}

Government can create a general business environment conducive to online marketing for the firms of Bangladesh. Besides this, some other solutions can be applied to solve online marketing problems and challenges. They are:

- Considering consumer's view at the time of web site development: When marketers develop web site must be considered consumer rather than their own. The companies are giving the customer more information about a particular product that they are needed and incorporate audio and video demos of their products which will help them in convincing the customers well.

- Easy to search: Ensure easy access of web site to the customer, which will be beneficial for them to search products that they intend to buy over the internet.

- Reduce cost of electronic infrastructure development: Availability of computer, telecommunication facility, internet connection, software, web sites can reduce the cost of electronic infrastructure.

- Legal and ethical issue: Must be considered legal and ethical issue on online marketing such as, IT Law, Cyber and Digital Signature law, other criminal and civil laws that incorporate clauses relating to electronic transactions.

- Maintain privacy and security: By developing softwares or another means try to maintain privacy and security.

- More attractive web site: Established more attractive web site that capture customer's attention and enforce them to make order.

- Reduce the rate of illeteracy: Ensuring education for all and specially providing computer education to the people that can increase the traffic on internet.

- Ensure continuous power supply: Government requires ensuring continuous power supply for the expansion of online marketing.

- Reduce illegal and unethical online promotion: Marketer needs to reduce illegal and unethical online promotion, provide proper information, and consider consumer betterment.

\section{CONCLUSION}

Internet is a globally interconnected network that includes millions of people, corporate body and government. The main reason is that the internet is still young and is constantly growing. Growth in technology reduces the costs of the consumer; so that, many more people are using their computers and internet daily. Digital customer data and electronic customer relationship management (ECRM) systems are also often grouped together under internet marketing. It converts traditional marketing into advance one by using information technology which increases efficiency in established marketing functions, transform traditional marketing strategy, and change consumer behavior through a power shift from organization to mouse holders. Hence Customer expects that online marketing will play a vital role to bridge the gap between businesses and end customers in a most effective manner.

\section{REFERENCES}

Ahmed S.F. and Bhuiyan M.B., 2006. "E-Marketing strategies in global context: the impact of country level effects", Journal of Business studies, vol.11, No-2.

Azad, A.S.M. Sohel, (2001), "E-Commerce as an emerging issue: relevant risks and security measures", The Cost \& Management, Journal of the Institute of Cost and Management Accounts of Bangladesh, Vol.-XXIX, No-5, September-October.

Bala, S.K., (2001), "E-Commerce in Bangladesh: Some lessons for the cost and management accounting profession", The Cost \& Management, Journal of the Institute of Cost and Management Accounts of Bangladesh, Vol.-XXIX, No-5, September-October.

Black A., (2004), "A strong net game”, Wall Street Journal, ISBN: 0-07-059855-X, Vol.-26(1), PP: R6-8.

Ching H.L.; Ellis P. (2004) Marketing in Cyberspace: What Factors Drive E-Commerce Adoption? Journal of Marketing Management, Volume 20, Numbers 3-4, pp. 409-429(21).

Danny S., (June 14, 2004). "Who Invented the Term "Search Engine Optimization"?", Journal of Journal of Marketing, American marketing association, Vol.28, pp: 25-34.

Ferdausi F., (2003), "Electronic Commerce in Bangladesh; An analysis of Hindrances and prospects", Journal of business studies, Vo.1- XXIV, No-1, June, PP: 213-219.

Ferdausi F., 2003. "Electronic Commerce in Bangladesh; An analysis of Hindrances and prospects", Journal of business studies, Vo.1- XXIV, No-1, June, PP: 213-219.

Ferrell O.C., 2009", Business: A changing world", $7^{\text {th }}$ edition, McGraw Hill Book Company, Newyork.

Garish W., 2011, "What is AffiliateMarketing and How to start withit?" October 04, (http://www.vast9.com/blogging/affiliatemarketing-start/)

Habib K., (2006), "E-commerce and internet service provider", Journal of Marketing Science, Volume 17, Number 2, pp. 29-32.

Habib, S. Ahsan., (2000), "E-Commerce Hype: Do we have the legal framework?" The Daily Star, July 18.

Ho, S. Y. (2006) "The Attraction of Internet Personalization to Web Users Electronic Markets", The Journal of Brand Management, Volume 16, Number 1, Number 1 pp. 41-50(10).

Kotler P, Armstrong G, 2010."Priciples of Marketing", $13^{\text {th }}$ edition, Prentice Hall, New Jersey.

Kotler P, Bowen J.T. and Makens J.C., 2010: "Marketing for hospitality and Tourism' $5^{\text {th }}$ edition, Pearson Education Inc. New Jersey. 
Malhotra Naresh K., 2006, "Marketing Research", $4^{\text {th }}$ edition, Pearson Education, p: 326.

Paul J., Lisa H. and Peter M. E. (2003) "e-Business Fundamentals" ISBN 0-203-40246-4 Master e-book ISBN, Taylor \& Francis Group, New York.

Philipp S., Bernd S. and Christophe V. B, (2010), "Referral Programs and Customer Value", Online Information Review, vol-35, No. 2, pp: 33-39.

Rahman, M. Lutfar, (2002), “E-Commerce and Bangladesh, Observer Magazine, May 10, PP: 3.

Rastogi, p. and Smith, S. M, (2004), Segmenting Internet shoppers based on their Web-usage-related lifestyle: A cross-cultural validation, Journal of Business Research, Vol. 28, pp: 49-58.

Richard Hoy, (2006), "What Is Online Marketing?" writers Weekly (April), part-1.

Robert, Mary, Lou. (2003), "Internet marketing: Integrating online and offline strategies", Mc-Graw Hill Book Company, Newyork.

Strauss J, El-Ansary A. and Frost R., 2006. "E-marketing" $4^{\text {th }}$ edition, Prentice Hall of India, New Delhi.

Strauss J. and Frost R., 2009. "E-marketing" $5^{\text {th }}$ edition, Prentice Hall of India Learning Private Limited, New Delhi.
Trattner, C., (2011), "Social Stream Marketing on Facebook: A Case Study", International Journal of Social and Humanistic Computing, Vol. 10, No.10 (20) CIA World Fact book, 2011

Twangcafe, (2010), Affiliate Marketing Networks Buyer's Guide (2006), Page 6, retrieved June.

Watson R.P., Leyland p., Berthon P. and Zinkham G., (2002), “Ucommerce: expanding the universe of marketing", Journal of the Academy of Marketing Science, ISBN: 0-211-23432-2, Vol.30(4), P: 333-47.

White, Jay D. (2007) Managing Information in the Public Sector. M.E. Sharpe. New York.

Yeasmin, I. and Siddika, H., (2011), “Consumers 'attitudes toward online purchasing in Dhaka city", Journal of Marketing.

Websites

http:/ / www.coursework4you.co.uk/sprtmrk8.htm, "Internet marketing: problems and prospects".

(2006),

http://www.ciprianginghina.com, (2010), the-advantages-anddisadvantages-of-online-marketing

http://ezinearticles.com, (2010), the-advantages-anddisadvantages-of-online-marketing.

http://www.iabuk.net/en/1/newsprocessor.qxml, Industry news processor, 19 April, 2011.

\section{SOCIAL SCIENCE RESEARCH NETWORK \\ 2171 Monroe Avenue, Suite 203, Rochester, NY 14618, USA http://www.ssrn.com/en/}

AJTP Link: http://www.ssrn.com/link/American-Journal-Trade-Policy.html 